\title{
急冷凝固 $\mathrm{Mg}_{97} \mathrm{Zn}_{1} \mathrm{RE}_{2}$ 合金の微細組織観察
}

\author{
糸井 貴臣 $*$. 矢野 佑一郎 $* *$. 筆谷 秀一 $* *$ \\ 河村 能人 $* * *$. 広橋 光治 $* *$
}

Journal of Japan Institute of Light Metals, Vol. 56, No. 10 (2006), pp. 543-549

\section{Microstructure observations of rapidly solidified $\mathrm{Mg}_{97} \mathrm{Zn}_{1} \mathrm{RE}_{2}$ alloys}

\author{
Takaomi ITOI*, Yuichiro YANO**, Syuichi FUDETANI** \\ Yoshihito KAWAMURA*** and Mitsuji HIROHASHI**
}

\begin{abstract}
The microstructure of ternary $\mathrm{Mg}_{97} \mathrm{Zn}_{1} \mathrm{RE}_{2}(\mathrm{RE}=\mathrm{La}, \mathrm{Ce}, \mathrm{Gd}, \mathrm{Tb}, \mathrm{Dy}$, Ho or $\mathrm{Er}$ ) melt-spun alloys annealed at $573 \mathrm{~K}$ for $1.2 \mathrm{ks}$ have been investigated in order to clarify the relationship between their microstructures and hardness. The $\mathrm{Mg}_{97} \mathrm{Zn}_{1} \mathrm{RE}_{2}$ alloys consisted of $\mathrm{Mg}$ grains with diameter ranging from 0.7 to $2 \mu \mathrm{m}$. Also, several $\mathrm{Mg}-\mathrm{Zn}-\mathrm{RE}$ ternary phases were observed inside Mg grain and at grain boundary. Long period stacking (LPS) structure characterized as 14H-type was formed inside some $\mathrm{Mg}$ grains in the $\mathrm{Mg}_{97} \mathrm{Zn}_{1} \mathrm{RE}_{2}$ ( $\mathrm{RE}=\mathrm{Gd}$, Tb, Dy, Ho or Er) alloys, respectively. The growth of 14H-type LPS structure from another $\mathrm{Mg}-\mathrm{Zn}-\mathrm{RE}$ ternary phase at grain boundary was recognized in the $\mathrm{Mg}_{97} \mathrm{Zn}_{1} \mathrm{RE}_{2}(\mathrm{RE}=\mathrm{Gd}$ or $\mathrm{Er}$ ) alloys, and also the electron diffraction pattern clearly indicated that the relationship between 14H-type LPS structure and $2 \mathrm{H}-\mathrm{Mg}$ was $(001)_{2 \mathrm{H}-\mathrm{Mg}} / /(0014)_{14 \mathrm{H}-\mathrm{Mg}}$, indicating the $14 \mathrm{H}-$ and $2 \mathrm{H}-\mathrm{Mg}$ were coexisted in the identical grain with certain relationship. On the other hands, although the LPS structure was not observed in the $\mathrm{Mg}_{97} \mathrm{Zn}_{1} \mathrm{RE}_{2}(\mathrm{RE}=\mathrm{La}$ or $\mathrm{Ce}$ ) alloys, a number of the $\mathrm{Mg}-\mathrm{Zn}-\mathrm{RE}(\mathrm{RE}=\mathrm{La}$ or $\mathrm{Ce}$ ) ternary phases with less than $50 \mathrm{~nm}$ dispersed in the Mg matrix, respectively. The higher hardness of the $\mathrm{Mg}_{97} \mathrm{Zn}_{1} \mathrm{RE}_{2}(\mathrm{RE}=\mathrm{La}$ or $\mathrm{Ce}$ ) alloys than the $\mathrm{Mg}_{97} \mathrm{Zn}_{1} \mathrm{RE}_{2}(\mathrm{RE}=\mathrm{Gd}, \mathrm{Tb}, \mathrm{Dy}$, Ho or Er) alloys originated in the formation of the numerous nano-size $\mathrm{Mg}-\mathrm{Zn}-\mathrm{RE}$ $(\mathrm{RE}=\mathrm{La}$ or $\mathrm{Ce})$ phases dispersed interior $\mathrm{Mg}$ grains in the $\mathrm{Mg}_{97} \mathrm{Zn}_{1} \mathrm{RE} 2(\mathrm{RE}=\mathrm{La}$ or $\mathrm{Ce})$ alloys.
\end{abstract}

(Received April 27, 2006 Accepted June 30, 2006)

Keywords: Mg-Zn-RE alloys, microstructure, TEM, hardness

\section{1. 緒言}

近年，ガスアトマイズ法により作製した $\mathrm{Mg}_{97} \mathrm{Zn}_{1} \mathrm{Y}_{2}(\mathrm{at} \%)$ RS-P/M 合金が 100 200 nm 程度の微細な $\mathrm{Mg}$ 粒で固化成形が 可能であり，600 MPa を越える降伏強度と $5 \%$ の塑性伸びを 兼敉備えた機械的特性を有していることから，非平衡プロセ スを利用した $\mathrm{Mg}$ 合金の創製とその機械的特性が注目を浴び ている ${ }^{1) ~ 4)}$ 。これらの優れた機械的特性は $\mathrm{Mg}$ 粒の微細化に 加えて，Mg，Zn および Y から構成される長周期相（ $\tau_{1}$ 相） が $\mathrm{Mg}$ 粒内に存在していることに起因していると考えられて いる。この長周期相は $\mathrm{Mg}-\mathrm{Zn}-\mathrm{Y}$ の 3 元状態図にも記載され ている安定相であり, $\mathrm{Mg}_{97} \mathrm{Zn}_{1} \mathrm{Y}_{2}$ (at \% ) 鋳造合金においては 体積分率で約 20 25\% 程度生成することが知られている ${ }^{5)}$ 。 このように, $\mathrm{Mg}-\mathrm{Zn}-\mathrm{RE}(\mathrm{RE}=$ 希土類元素) 合金急冷材の組 織と機械的特性について興味がもたれている。これまでの研 究において, 液体急冷法により作製した $\mathrm{Mg}_{97} \mathrm{Zn}_{1} \mathrm{RE}_{2}(\mathrm{RE}=$ 希土類元素）合金に熱処理を施した試料について，RE 元素 に La および Ce を用いた合金が密着曲げにより脆性破断する あのの，159 168 HV と著しく高い硬さを示すこと，また RE 元素に $\mathrm{Y}, \mathrm{Sm}, \mathrm{Gd}, \mathrm{Tb}, \mathrm{Dy}, \mathrm{Ho}$ むしくは Er を添加した合
金では密着曲げが可能であり 92〜102HV の高い硬さを示す が， RE 元素に La および Ce を用いた合金ほど硬くないこと が報告されている ${ }^{6)}$ 。

これらの硬さの変化には $\mathrm{Mg}$ 粒の粒径や $\mathrm{Mg}-\mathrm{Zn}-\mathrm{RE}$ からな る 3 元相が影響していると考えられているが，これら 3 元相 は未知化合物であることが多く, その構造の詳細は知られて おらず，また添加する $\mathrm{RE}$ 元素の違いにより大きく硬さが異 なる組織的な理由は明らかになっていない。

比強度を重視する $\mathrm{Mg}$ 合金の開発において，わずかな添加 元素を有効的に強度に結びつけるために微細組織観察は必要 不可欠である。そこで本研究では液体急冷法で作製した $\mathrm{Mg}_{97} Z_{1} \mathrm{RE}_{2}$ 合金の熱処理材について TEM 観察を行い, 組織 と硬さの関連を明らかにすることを目的とした。

\section{2. 実 験方法}

純度 $99.9 \%$ の純 $\mathrm{Mg}, \mathrm{Zn}$ および種々の希土類元素 $(\mathrm{RE}=\mathrm{La}$, $\mathrm{Ce}, \mathrm{Gd}, \mathrm{Tb}, \mathrm{Dy}, \mathrm{Ho}$ もしくは Er）を用いて電気炉にて炭酸 ガス雾囲気下で $\mathrm{Mg}_{97} \mathrm{Zn}_{1} \mathrm{RE}_{2}$ (at\%) 合金を作製した。るつぼ はカーボン製のものを使用し，溶解後に $\phi 26 \times 20 \mathrm{~mm}$ の鋳型 に鋳込んで母合金を作製した。作製した種々の $\mathrm{Mg}_{97} \mathrm{Zn}_{1} \mathrm{RE}_{2}$

\footnotetext{
*千葉大学工学部（干 263-8522 千葉市稲毛区弥生町 1-33)。Department of Electronics and Mechanics Engineering, Chiba University (1-33 Yayoi-cho, Inage-ku, Chiba-shi, Chiba, 263-8522). E-mail: itoi@faculty.chiba-u.jp

**千葉大学大学院工学研究科 (千葉市)。Graduate school of Engineering, Chiba University (Chiba-shi, Chiba).

***熊本大学大学院自然科学研究科 (熊本市)。Graduate school of Science and Technology, Kumamoto University (Kumamoto-shi, Kumamoto).
} 
（at\%）合金を母合金として，単ロール液体急冷法により，厚 さが約 $20 \mu \mathrm{m}$, 幅が約 $1 \mathrm{~mm}$ の薄帯試料を作製した。溶解用 のノズルは石英製のものを用い，1気圧のアルゴン雾囲気中 において急冷処理を行った。母合金および急冷試料の表記に ついてはすべて仕込みの組成である。作製した薄帯試料は酸 化を防ぐことを目的として，ガラス管に真空封入（1.5× $\left.10^{-4} \mathrm{~Pa}\right)$ の後, $573 \mathrm{~K}$ で $1.2 \mathrm{ks}$ の熱処理を行った。熱処理を施 した試料について，ラッピングシートフィルム（粒度 $1 \mu \mathrm{m} ）$ を用いて乾式研磨により，7〜8 $\mu \mathrm{m}$ に薄帯化した後，イオン ミリングによりさらに薄帯化した。イオンミリングは DIM600 を用い, 電圧を $2.5 \mathrm{kV}$, 電流を $0.5 \mathrm{~mA}$ としてミリングを行い, 透過型電子顕微鏡（TEM）用の観察試料とした。作製した試 料は TEM（JEM-4000EX と JEM-3000F）を用いて組織観察を 行った。加速電圧はそれぞれ $400 \mathrm{kV}$ および $300 \mathrm{kV}$ とし, EDS 分析については $3000 \mathrm{~F}$ を用いてビームを $10 \mathrm{~nm}$ 程度まで絞り 込んで分析した。EDS 分析はV Voyager 分析システム（Noran instrument）を用いて行い, 分析結果は ZAF 補正を行い, 化 学組成の見積もりを行った。

\section{3. 実験結果および考察}

Fig. 1 に $\mathrm{Mg}_{97} \mathrm{Zn}_{1} \mathrm{RE}_{2}$ (at\%) 合金を $573 \mathrm{~K}$ で $1.2 \mathrm{ks}$ の熱処 理を行った試料について，添加した種々の RE 元素とその硬 さの関係をグラフ化したものを示す。また，図には密着曲げ が可能であった試料についてはD (Ductile), 不可能であった 試料ではB (Brittle) と示している。それぞれの試料の硬さ はいずれあ $90 \mathrm{HV}$ 以上であり, 高い硬さを示すが, 添加した $\mathrm{RE}$ 元素の種類により硬さが異なることがわかる。 $\mathrm{RE}$ 元素に $\mathrm{Gd}, \mathrm{Tb}, \mathrm{Dy}, \mathrm{Er}$ および Ho を用いた試料では Ductile であり, 硬さは 92 102 HV の範囲である。一方, RE 元素に $\mathrm{La}$ と $\mathrm{Ce}$ を用いた合金については, Brittleであるが他の RE 元素と比 較して 50 以上も硬く，それぞれ $159 \mathrm{HV}$ および $168 \mathrm{HV}$ を示 す。添加した $\mathrm{Zn}$ や RE 元素の添加量が同じであるにあかかわ らず, このように硬さに大きく違いが出る理由としては, 結 晶粒径や生成する化合物相等の組織の違いが理由に挙げられ る。そこで，添加した RE 元素とこの硬さの違いを組織的に 明らかにするために各試料について TEM 観察を行った。Fig. 2 に $\mathrm{Mg}_{97} \mathrm{Zn}_{1} \mathrm{Gd}_{2}$ (at \%) 合金について $573 \mathrm{~K}$ で $1.2 \mathrm{ks}$ の熱処理 を行った試料について TEM 観察を行った結果を示す。以下, TEM 観察を行った試料はすべてこの熱処理条件であり，熱 処理合金と記す。図からは, $\mathrm{Mg}$ 粒径は $0.5 \sim 1.8 \mu \mathrm{m}$ であり, 粒界に $100 \mathrm{~nm}$ 程度の化合物が存在している様子が観察され る。 $\mathrm{Mg}$ 粒の平均粒径はおよそ $1.3 \mu \mathrm{m}$ であった。この試料に ついて, Mg 粒と粒界近傍について拡大した TEM 写真を Fig. 3 に示す。また, 電子線を $10 \mathrm{~nm}$ 程度まで絞り, $\mathrm{Mg}$ 粒内（領 域 A）および粒界化合物（領域 B）についてナノ EDS 分析を 行った結果をあわせて示す。 EDS 分析の結果を見ると, $\mathrm{Mg}$ 粒内の組成は $\mathrm{Mg}-2 \mathrm{at} \% \mathrm{Gd}$ を示し, ほぼ $\mathrm{Mg}$ で構成されてお り, 添加した Zn は確認されなかった。一方, 粒界化合物の 組成は $\mathrm{Mg}-15 \mathrm{at} \% \mathrm{Zn}-16 \mathrm{at} \% \mathrm{Gd}$ であり $\mathrm{Mg}-\mathrm{Zn}-\mathrm{Gd}$ の 3 元化合 物であることがわかった。また， $\mathrm{Mg}$ 粒には矢印で示すよう にしばしば $\mathrm{Mg}$ 粒内を縦断する微細なラメラ組織の存在が観 察された。Fig. 4 に微細なラメラ相が観察された $\mathrm{Mg}$ 粒内の TEM 写真と図中に○で示した領域 A において [110］入射 から得られた電子線回折 (ED) パターン，および領域 B お

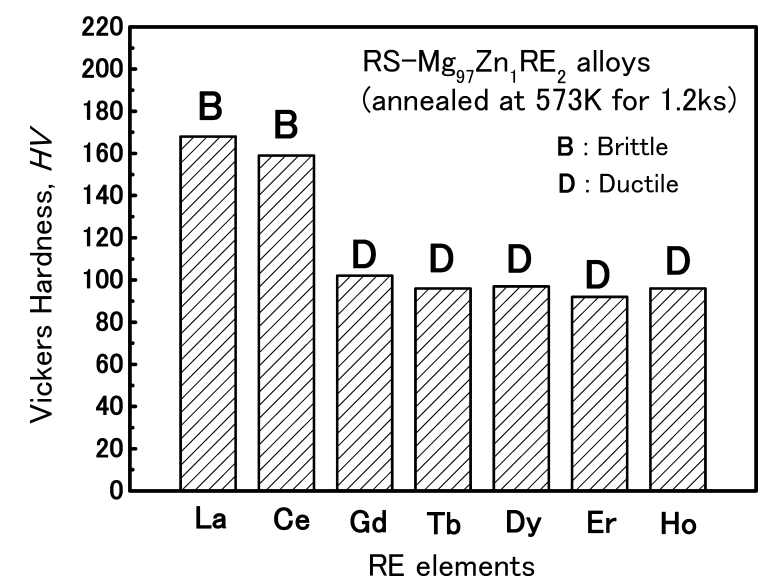

Fig. 1 Vickers hardness of the $\mathrm{Mg}_{97} \mathrm{Zn}_{1} \mathrm{RE}_{2}$ ( $\mathrm{RE}=\mathrm{La}, \mathrm{Ce}$, $\mathrm{Gd}, \mathrm{Tb}, \mathrm{Dy}, \mathrm{Ho}$ or Er) alloys annealed at $573 \mathrm{~K}$ for $1.2 \mathrm{ks}$.

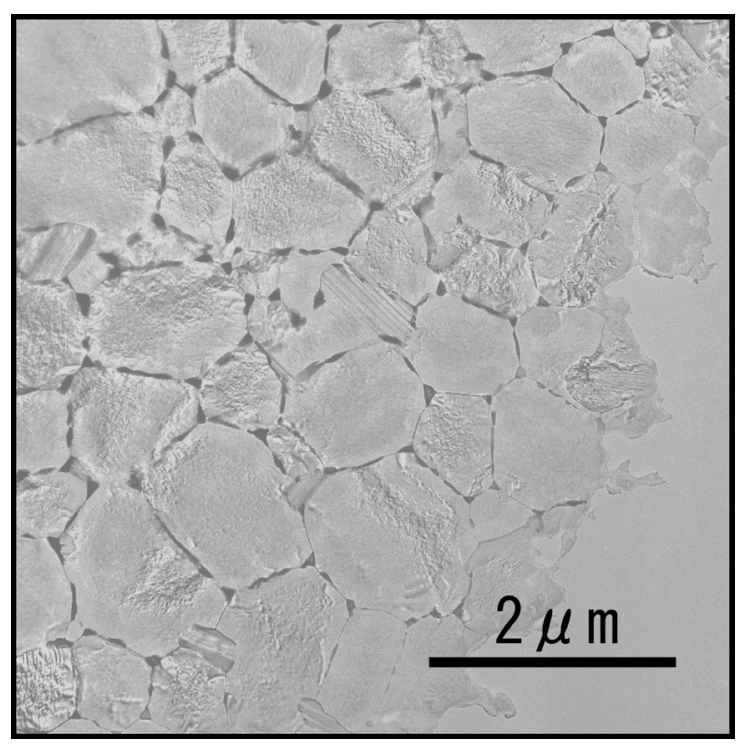

Fig. 2 TEM image of the $\mathrm{Mg}_{97} \mathrm{Zn}_{1} \mathrm{Gd}_{2}$ alloy annealed at $573 \mathrm{~K}$ for $1.2 \mathrm{ks}$.

よび領域 C から得られた EDS 分析結果を示す。 $\mathrm{ED}$ パターン からは $00 \mathrm{n} / 14\left(^{(002)}{ }_{\mathrm{hcp}}\right.$ に相当) と $-11 \mathrm{n} / 14$ のスポットが 観察され, このラメラ相は $\mathrm{c}=3.64 \mathrm{~nm}$ の $14 \mathrm{H}$-type の長周期相 であることが明らかとなった。また, 図中の ED パターンは 長周期相と $\mathrm{Mg}$ 相との両相から重秝て得られていることから $\mathrm{Mg}$ と $(002)_{\mathrm{Mg}} / /(0014)_{\mathrm{LPS}}$ の関係で存在していることも明ら かとなった。領域 C の EDS 分析結果より, この長周期相の 組成は $\mathrm{Mg}-7 \mathrm{at} \% \mathrm{Zn}-7 \mathrm{at} \% \mathrm{Gd}$ であり，また領域 B の化合物は $\mathrm{Mg}-6 \mathrm{at} \% \mathrm{Zn}-14 \mathrm{at} \% \mathrm{Gd}$ であり，長周期相の組成と比較して， より $\mathrm{Gd}$ 濃度が高い 3 元化合物であることがわかった。図中 に矢印で示すように長周期相は粒界化合物から成長してきて いるように伺える。Fig. 5 に長周期相について [110］入射 で得られた高分解能電子顕微鏡写真を示す。写真より, この 構造は $\mathrm{c}=3.64 \mathrm{~nm}$ の周期を持つ $\mathrm{ABABABACBCBCBC}$ の積層構 造を持つことが明らかとなった。この積層構造は, $\mathrm{Mg}_{97} \mathrm{Zn}_{1} \mathrm{Y}_{2}$ 合金に観察される 14H-type の長周期相と積層構造が同じで あり，また Fig. 4 に示すように, EDS 分析結果によるZn お よび RE 濃度もほぼ同じであった ${ }^{5)}$ 。Fig. 6 に $\mathrm{Mg}_{97} \mathrm{Zn}_{1} \mathrm{Er}_{2}$ (at\%) 合金熱処理材の TEM 写真を示す。図からは約 0.4 1.8 

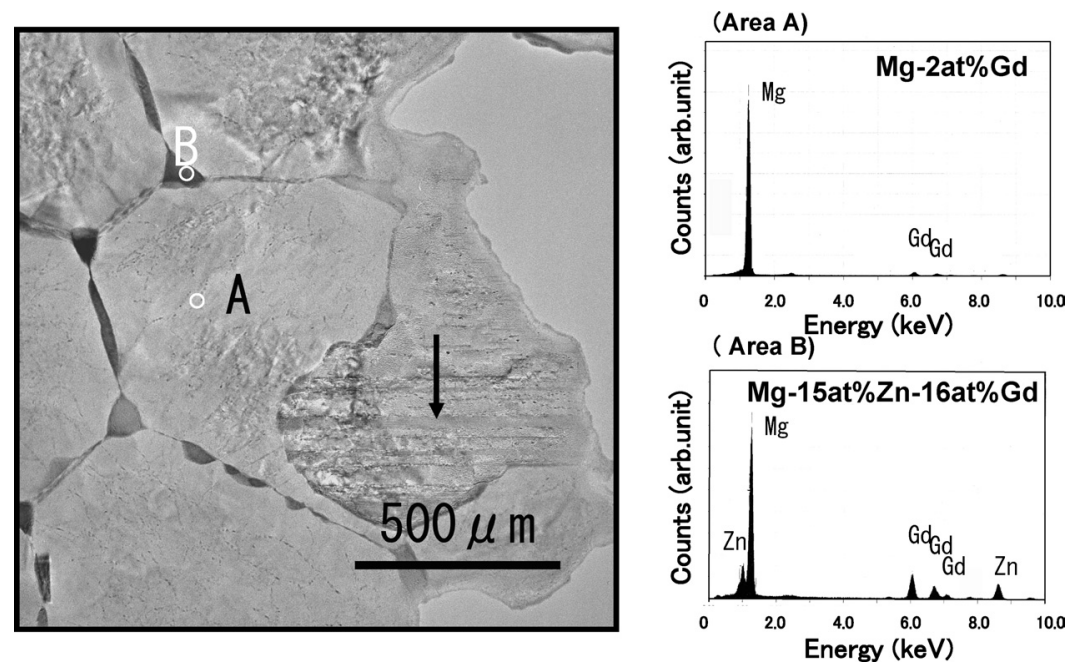

Fig. 3 Enlarged TEM image of $\mathrm{Mg}$ grain and grain boundary phases observed in the $\mathrm{Mg}_{97} \mathrm{Zn}_{1} \mathrm{Gd}_{2}$ alloy. The EDS spectra taken from $\mathrm{Mg}$ grain (Area A) and grain boundary phase (Area B) are also indicated.
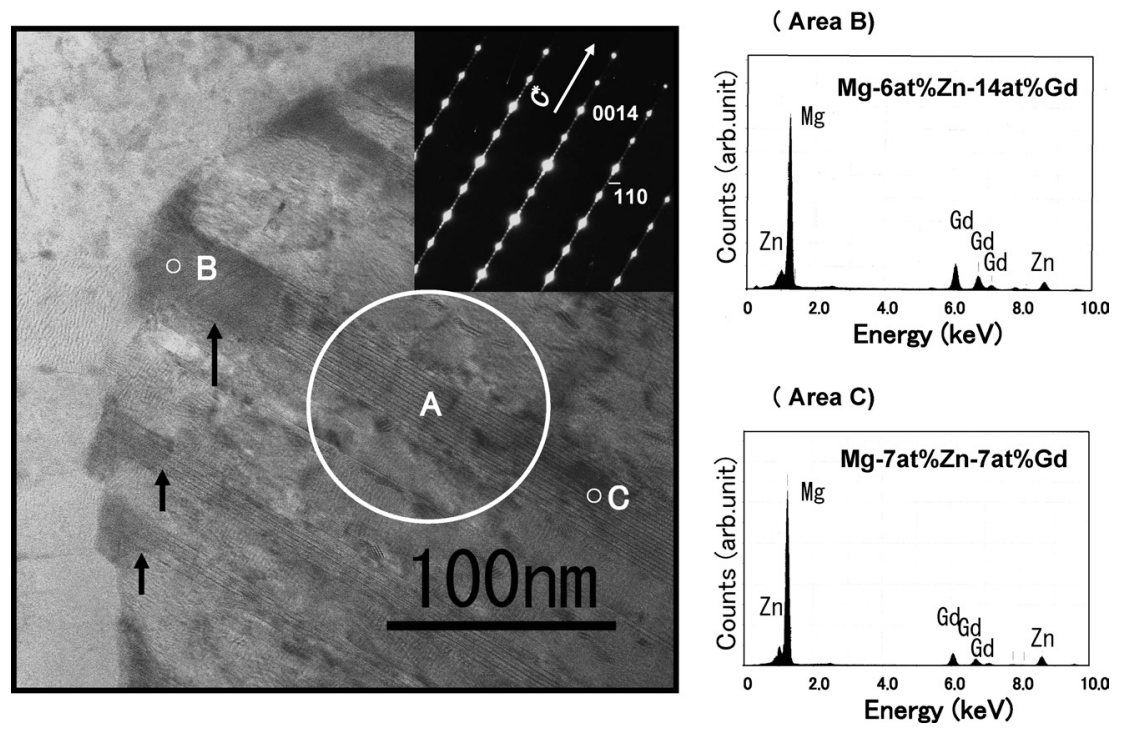

Fig. 4 TEM image of interior $\mathrm{Mg}$ grain with fine lamellar structure and SADP taken from area $\mathrm{A}$ in the $\mathrm{Mg}_{97} \mathrm{Zn}_{1} \mathrm{Gd}_{2}$ alloy. The EDS spectra taken from grain boundary phase (Area B) and fine lamellar structure (Area C) are also indicated.

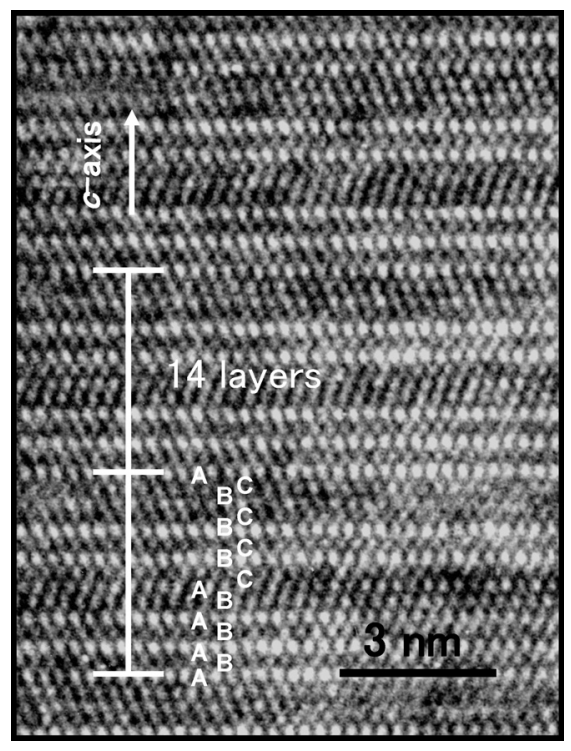

Fig. 5 HRTEM image of 14H-type LPS structure observed from [110] zone axis in the $\mathrm{Mg}_{97} \mathrm{Zn}_{1} \mathrm{Gd}_{2}$ alloy.

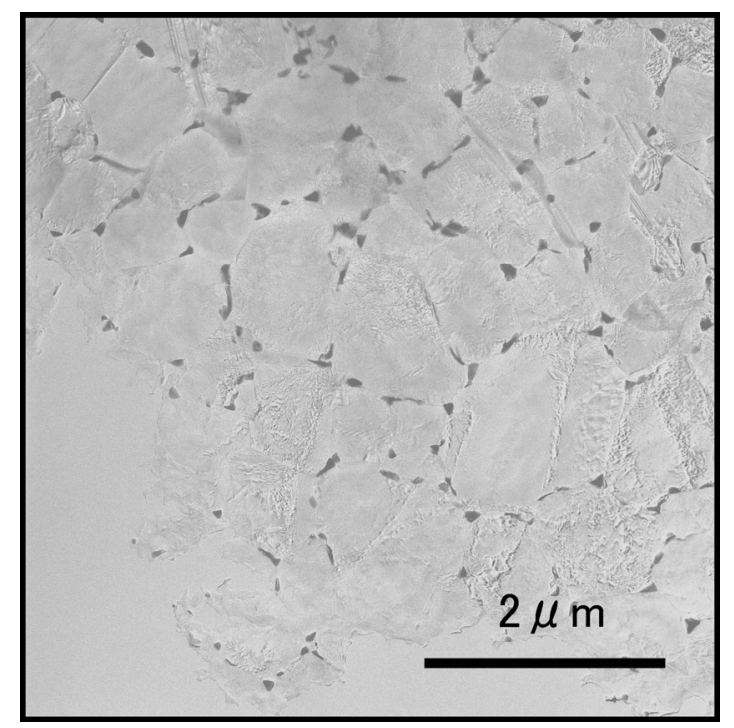

Fig. 6 TEM image of the $\mathrm{Mg}_{97} \mathrm{Zn}_{1} \mathrm{Er}_{2}$ alloy annealed at $573 \mathrm{~K}$ for $1.2 \mathrm{ks}$. 

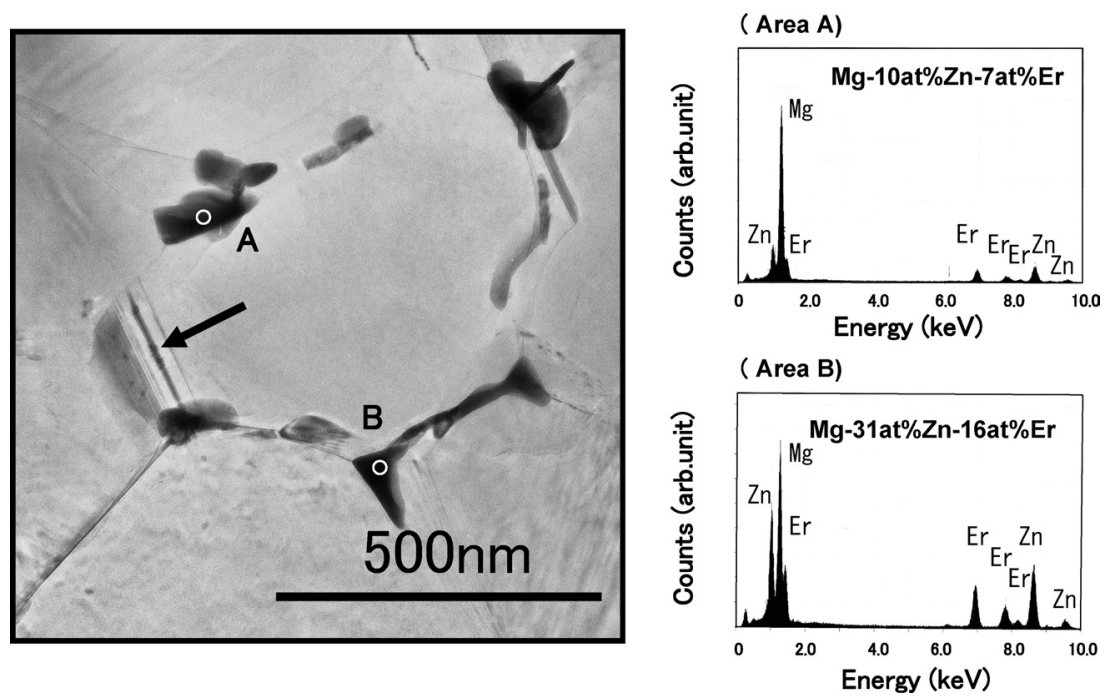

Fig. 7 Enlarged TEM image of $\mathrm{Mg}$ grain and grain boundary phases in the $\mathrm{Mg}_{97} \mathrm{Zn}_{1} \mathrm{Er}_{2}$ alloy. The EDS spectra taken from grain boundary phase $-\mathrm{A}$ and $-\mathrm{B}$ are also indicated.

$\mu \mathrm{m}$ の $\mathrm{Mg}$ 粒とその粒界に $100 \mathrm{~nm}$ 程度の粒界化合物が生成し ていることがわかる。 $\mathrm{Mg}$ 粒の平均粒径は約 $1.0 \mu \mathrm{m}$ であった。 Fig. 7 に $\mathrm{Mg}$ 粒および粒界近傍の拡大写真と領域 $\mathrm{A}$ および領 域 Bで得られた EDS 分析の結果を示す。これらの粒界化合

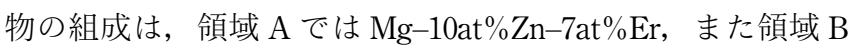
は Mg-31at \% Zn-16at\%Erであり，その他の粒界に生成してい る化合物の組成を調べた結果, ともに $\mathrm{Mg}-\mathrm{Zn}-\mathrm{Er}$ の 3 元化合 物であり，この 2 種類にほぼ大別されることがわかった。ま た，Fig. 7 からは， $\mathrm{Mg}_{97} Z_{1} \mathrm{Gd}_{2}$ 合金と同様に $\mathrm{Mg}$ 粒内に矢印 で示すように，しばしば微細なラメラ組織が観察された。Fig. 8 に $\mathrm{Mg}$ 粒内の組織を拡大した TEM 写真を示す。 $\mathrm{Mg}$ 粒内に はしばしば，領域 Cに示されるようなラメラ組織が観察され た。［110］入射により領域 Cおよび Dより得られた $\mathrm{ED}$ パ ターンをそれぞれ図中に示す。 $\mathrm{ED}$ パターンより領域 D は通 常の $2 \mathrm{H}-\mathrm{Mg}$ であるのに対し, 領域 C から得られた ED パター ンからは 14H-type の長周期相であることがわかった。またC と $\mathrm{D}$ の $\mathrm{ED}$ パターンからあ長周期構造は $2 \mathrm{H}-\mathrm{Mg}$ と (002) ${ }_{\mathrm{Mg}} / /$ (0014) LPS の関係で存在していることも明らかとなった。

Fig. 4 に観察されるように, 長周期相は粒界化合物から $\mathrm{Mg}$ 粒内に成長する傾向がしばしば観察される。西田らは $\mathrm{Mg}_{97} \mathrm{Zn}_{1} \mathrm{Y}_{2}(\mathrm{at} \%)$ 合金急冷材について組織観察を行い, $\mathrm{Mg}$ 粒界に生成した $\mathrm{Mg}, \mathrm{Zn}$ および $\mathrm{Y}$ を含む非晶質相が熱処理に より $\mathrm{Mg}$ 粒内に長周期相として生成・成長することを確認し ている ${ }^{7)}$ 。Fig. 3 や Fig. 4 に観察される粒界化合物について は, ナノディフラクションにより調べた結果, 非晶質相では なく，結晶構造を持つことが明らかとなっているが，おそら く非平衡相であると考えられる。 RE 元素に Gdや $\mathrm{Er}$ を用い た合金においては，熱処理により準安定状態にある粒界化合 物から長周期相が生成・成長していると考えられる。 $\mathrm{Mg}$ 粒 内に生成する長周期構造は Luo らにより $\mathrm{Mg}-\mathrm{Zn}-\mathrm{Y}-\mathrm{Zr}$ 合金中 に生成する 18R-type の積層構造を有する相として報告されて おり, $\mathrm{Mg}-\mathrm{Zn}-\mathrm{Y}$ の 3 元状態図に存在する $\tau_{1}$ 相として知られ ている ${ }^{8)}$ 。近年，ガスアトマイズ法で作製した $\mathrm{Mg}_{97} \mathrm{Zn}_{1} \mathrm{Y}_{2}$ (at \% ) RS-P/M 合金中に生成する長周期相が，阿部らにより 高角度散乱電子を用いて結像した暗視野走査透過型電子顕微 鏡（HAADF-STEM）により詳細に調べた結果が報告されて
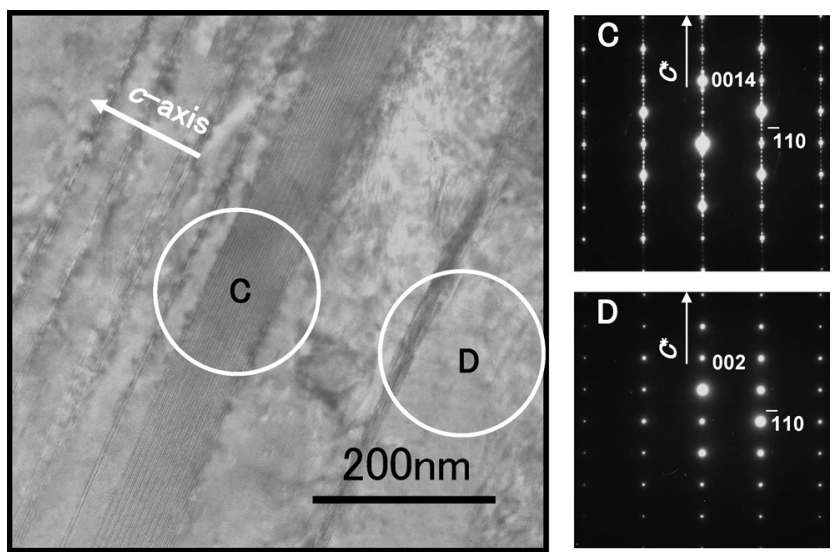

Fig. 8 TEM image of inside $\mathrm{Mg}$ grain with fine lamellar structure in the $\mathrm{Mg}_{97} \mathrm{Zn}_{1} \mathrm{Er}_{2}$ alloy. The SADPs taken from area $-\mathrm{C}$ and $-\mathrm{D}$ are also indicated.

いる ${ }^{9)}$ 。その結果, この構造は単に $\mathrm{Mg}$ の積層構造が長周期 化したものではなく，6原子層中に 2 原子層にわたって添加 した Zn と Y が濃縮していることが明らかとなり, 積層秩序 だけでなく化学的にも規則化した構造を持つことが大きな特 徵であるとわかった。また $14 \mathrm{H}-$ type の長周期構造は $\mathrm{Mg}_{97} \mathrm{Zn}_{1} \mathrm{Y}_{2}$ (at\%) 液体急冷合金中に生成することが網谷らに より初めて報告されている ${ }^{10)}$ 。さらに，松田らにより $\mathrm{Mg}_{97} \mathrm{Zn}_{1} \mathrm{Y}_{2}$ (at \% ) 液体急冷合金の熱処理材には, 10H, 18R, $24 \mathrm{R}$ など，種々の周期が存在することも報告されている ${ }^{11) 。 ~}$

Fig. 9 に $\mathrm{Mg}_{97} \mathrm{Zn}_{1} \mathrm{La}_{2}(\mathrm{at} \%)$ 合金熱処理材の TEM 写真を示 す。 $0.3 \sim 1 \mu \mathrm{m}$ 程度の $\mathrm{Mg}$ 粒とその粒界に幅 $100 \mathrm{~nm}$ 程度の粒 界化合物が $\mathrm{Mg}$ を取り囲むように生成していること, また $\mathrm{Mg}$ 粒中に $100 \mathrm{~nm}$ 以下の微細な粒状の化合物が存在しているこ とが確認された。 $\mathrm{Mg}$ 粒の平均粒径は約 $0.7 \mu \mathrm{m}$ であり, Fig. 2 や Fig. 6 に観察されるように, $\operatorname{Mg}_{97} Z_{1} \mathrm{Gd}_{2}($ at \% ) や $\mathrm{Mg}_{97} \mathrm{Zn}_{1} \mathrm{Er}_{2}$ (at\%) 合金と比較して $\mathrm{Mg}$ 粒径に大きな差は認め られなかった。Fig. 10 に Mg 粒界近傍の拡大写真および $\mathrm{Mg}$ 粒内について [001］入射により得られた ED パターンをあわ せて示す。図中に矢印で示した部分が粒界の化合物であり, $\mathrm{Mg}$ 粒界に断続的に幅 30 50 nm 程度の大きさで存在してい 
る。EDS 分析の結果, この粒界化合物の組成は $\mathrm{Mg}$ 9at $\%$ Zn- 11 at $\% \mathrm{La}$ であり, Mg-Zn-La の 3 元化合物であった。 また $\mathrm{Mg}$ 粒内には $30 \mathrm{~nm}$ 以下の微細な化合物が高密度に分散 していることがわかる。 $\mathrm{ED}$ パターンからは, $\mathrm{Mg}$ の基本格子

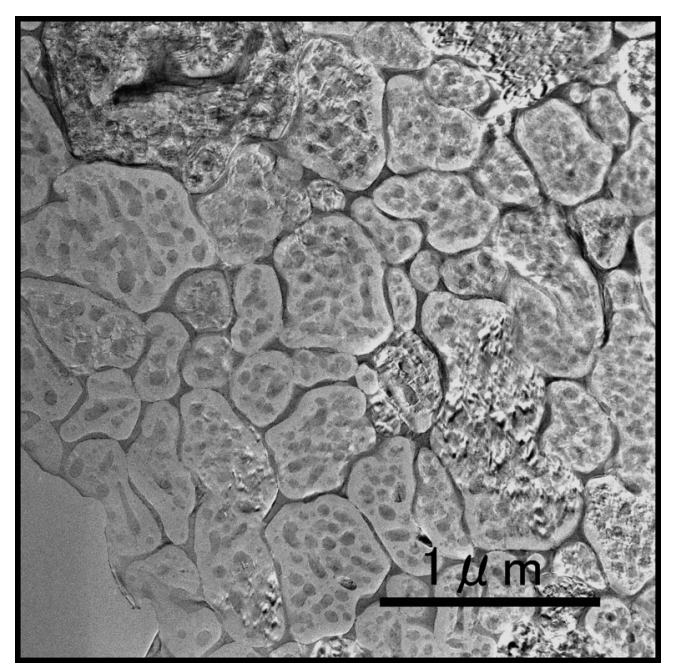

Fig. 9 TEM image of the $\mathrm{Mg}_{97} \mathrm{Zn}_{1} \mathrm{La}_{2}$ alloy annealed at $573 \mathrm{~K}$ for $1.2 \mathrm{ks}$.
反射に加えて $\mathrm{Mg}$ 粒内に分散されている化合物に相当すると 考えられるスポットが観察された。現段階ではこの微細な化 合物の結晶構造は明らかとなっていないが, $\mathrm{ED}$ パターン中 に矢印で示したように $\mathrm{A}=2.73 \mathrm{~nm}$ および $\mathrm{B}=4.53 \mathrm{~nm}$ と, 分散 している化合物の格子定数は $\mathrm{Mg}$ と比較して大きな格子定数 を有していると考えられる。Fig. 11 に Mg 粒内に生成した 化合物の HRTEM 写真を示す。図からは $15 \mathrm{~nm}$ 程度の化合物 が $\mathrm{Mg}$ 母相と整合性を保って生成していることが明らかと なった。また, 図中の A で示した領域について EDS 分析を 行った結果, 化合物の組成は $\mathrm{Mg}-10 \mathrm{at} \% \mathrm{Zn}-5 \mathrm{at} \% \mathrm{La}$ であり, 粒界の化合物とは異なる組成を示した。以上の結果から, $\mathrm{Mg}$ 粒と 2 種類の $\mathrm{Mg}-\mathrm{Zn}-\mathrm{La}$ 化合物で構成していることがわかっ た。Fig. 12 に液体急冷法により作製した $\mathrm{Mg}_{97} \mathrm{Zn}_{1} \mathrm{Ce}_{2}$ (at\%) 合金熱処理材の TEM 写真を示す。TEM 写真からは $1 \sim 3 \mu \mathrm{m}$ 程度の $\mathrm{Mg}$ 粒と $\mathrm{Mg}$ 粒内に $100 \mathrm{~nm}$ 以下の微細な化合物が生成 している様子が観察された。 $\mathrm{Mg}$ 粒の平均粒径は約 $2 \mu \mathrm{m}$ で あった。また粒界に $50 \mathrm{~nm}$ 程度の粒界化合物が存在していた。

Fig. 13 に粒界近傍の TEM 写真と $\mathrm{Mg}$ 粒内について [001] 入射により得られた ED パターンをあわせて示す。図中に矢 印で示したように粒界には幅 10 30 nm 程度の化合物が存在 しているのがわかる。また $\mathrm{Mg}$ 粒内には $10 \sim 30 \mathrm{~nm}$ 程度の化
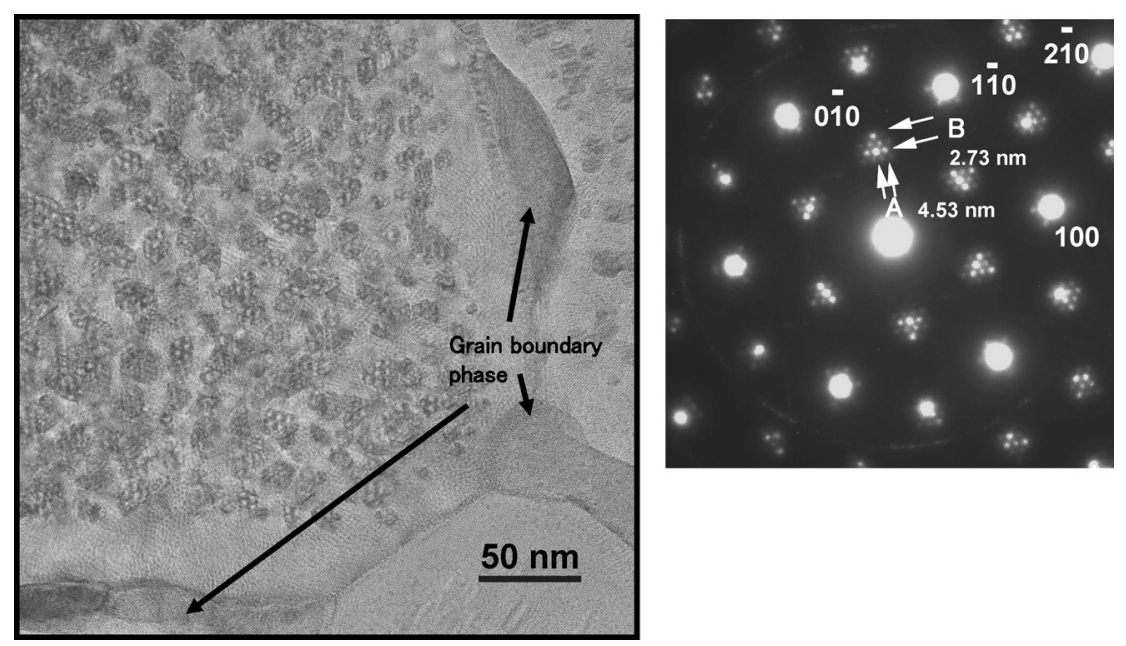

Fig. 10 TEM image and SADP taken from Mg grain with fine compounds observed from [001] zone axis in the $\mathrm{Mg}_{97} \mathrm{Zn}_{1} \mathrm{La}_{2}$ alloy.
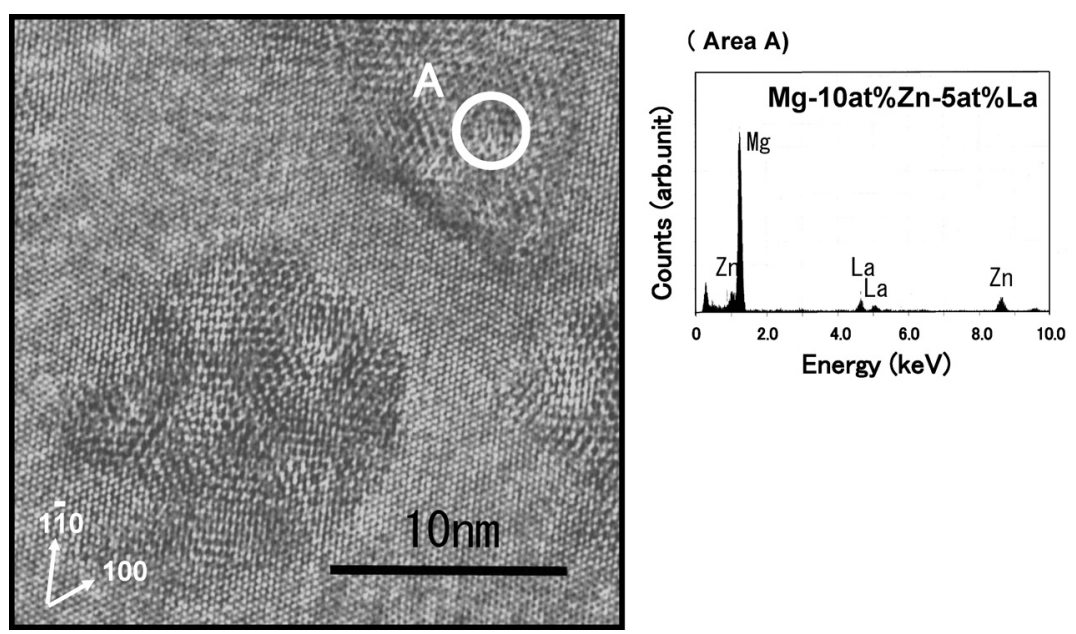

Fig. 11 HRTEM image and EDS spectrum taken from compound A dispersed in the Mg matrix observed from [001] zone axis in the $\mathrm{Mg}_{97} \mathrm{Zn}_{1} \mathrm{La}_{2}$ alloy. 
合物が分散していることもわかる。ED パターンは Fig. 10 と 類似したパターンであり，この $\mathrm{ED}$ パターンからあ化合物相

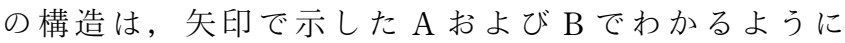
$\mathrm{Mg}_{97} \mathrm{Zn}_{1} \mathrm{La}_{2}$ 合金に生成する化合物と同様に，比較的格子定数 の大きい化合物であることがわかる。また，EDS 分析の結果， 粒界および粒内に生成している化合物は，それぞれ濃度は異 なるあのの，いずれも $\mathrm{Mg}-\mathrm{Zn}-\mathrm{Ce}$ の 3 元化合物であった。Fig. 12 および Fig. 13 から， $\mathrm{Mg}_{97} \mathrm{Zn}_{1} \mathrm{Ce}_{2}$ 合金の組織はやや $\mathrm{Mg}$ 粒径 は大きいものの, $\mathrm{Mg}_{97} \mathrm{Zn}_{1} \mathrm{La}_{2}$ 合金熱処理材と生成している化

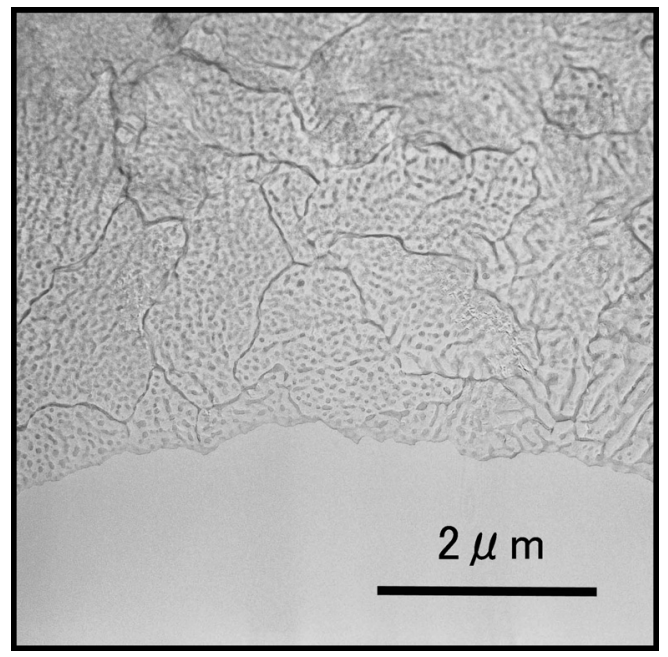

Fig. 12 TEM image of the $\mathrm{Mg}_{97} \mathrm{Zn}_{1} \mathrm{Ce}_{2}$ alloy annealed at $573 \mathrm{~K}$ for $1.2 \mathrm{ks}$
合物の構造やその生成・分散状態屯類似していると言える。 この微細な化合物は, $\mathrm{Mg}_{97} Z_{1} \mathrm{La}_{2}$ 合金および $\mathrm{Mg}_{97} \mathrm{Zn}_{1} \mathrm{Ce}_{2}$ 合金 において，急冷凝固時にすでに生成していることが確認され ており，熱処理により析出した相ではなく，急冷凝固時に生 成・分散したあのであると考えられる。Fig. 14 に $\mathrm{Mg}_{97} \mathrm{Zn}_{1} \mathrm{RE}_{2}$ 合金熱処理材について RE 元素に（a） Dy，（b） $\mathrm{Tb}$ および（c）Ho を用いた試料の TEM 像を示す。いずれの 組織も抢よそ $0.4 \sim 2 \mu \mathrm{m}$ 程度の $\mathrm{Mg}$ 粒とその粒界に $100 \mathrm{~nm}$ 程 度の化合物が生成していることがわかる。粒界に存在する化 合物はいずれも $\mathrm{Mg}-\mathrm{Zn}-\mathrm{RE}$ の 3 元相であり, $\mathrm{Mg}$ 粒の平均粒 径は（a）Dy，（b）Tb および（c）Ho においてそれぞれ，1.1， 1.5 および $1.0 \mu \mathrm{m}$ であった。また, これらの組織観察の結果, いずれの組成においてもしばしば $\mathrm{Mg}$ 粒内に $\mathrm{Mg}, \mathrm{Zn}$ および RE 元素から構成される $14 \mathrm{H}$-type の長周期相が観察された。

以上の結果から，作製した $\mathrm{Mg}_{97} \mathrm{Zn}_{1} \mathrm{RE}_{2}$ 合金熱処理材 （RE=La，Ce，Gd，Tb，Dy，Hoもしくは Er）の組織は Mg 粒之 $\mathrm{Mg}-\mathrm{Zn}-\mathrm{RE}$ の 3 元相から構成されていることが明らかと なった。各試料の $\mathrm{Mg}$ 粒の平均粒径は $0.7 \sim 2.0 \mu \mathrm{m}$ であり, $\mathrm{RE}$ 元素に依存せず大きな違いは認められなかった。しかし, RE 元素に $\mathrm{La}$ や Ce を用いた場合とそれ以外の $\mathrm{Gd}, \mathrm{Tb}, \mathrm{Dy}, \mathrm{Ho}$ や Er を用いた場合では, 生成する化合物の形態と分散状態 が異なる。 RE 元素に $\mathrm{La}$ や $\mathrm{Ce}$ を用いた場合, 50 ～100 nm 程 度の粒界化合物が $\mathrm{Mg}$ 粒を取り囲むように存在し, さらに $30 \mathrm{~nm}$ 程度の化合物が $\mathrm{Mg}$ 粒内に高密度に分散している。一 方， $\mathrm{RE}$ 元素に $\mathrm{Gd}, \mathrm{Tb}, \mathrm{Dy}, \mathrm{Ho}$ や $\mathrm{Er}$ を用いた場合，粒界 には $100 \mathrm{~nm}$ 程度の粒状の化合物が，また $\mathrm{Mg}$ 粒内にはしばし
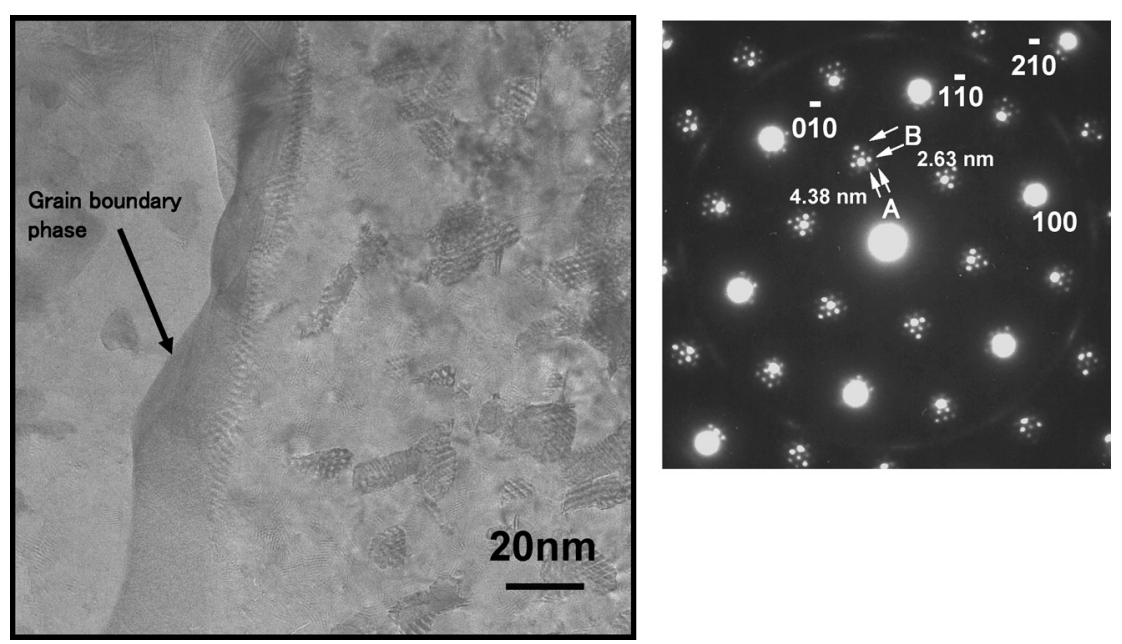

Fig. 13 TEM image and SADP taken from Mg grain with fine compounds observed from [001] zone axis.
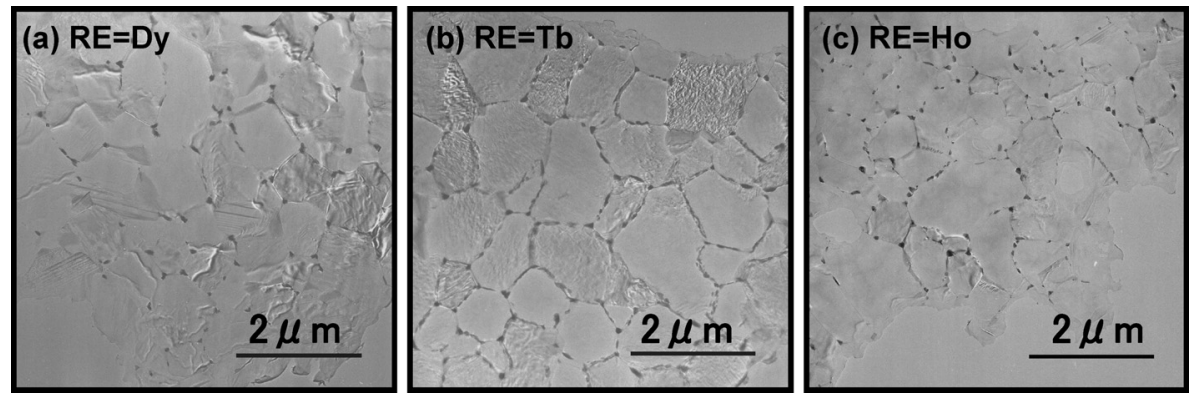

Fig. 14 TEM images of the $\mathrm{Mg}_{97} \mathrm{Zn}_{1} \mathrm{RE}_{2}$ alloys annealed at $573 \mathrm{~K}$ for $1.2 \mathrm{ks}$ with RE elements of (a) Dy, (b) Tb and (c) Ho, respectively. 
ば 14H-type の長周期相が観察される。 $\mathrm{Mg}_{97} \mathrm{Zn}_{1} \mathrm{RE}_{2}$ 合金に生 成する 3 元化合物における $\mathrm{Mg}$ 濃度は EDS 分析の結果 RE 元 素に La や Ce を用いた場合では 80 87 at \% であり，それ以外 の RE 元素を使用した場合に生成する 3 元化合物は $53 \sim 87 \%$ である。 La と Ce はともに $\mathrm{Mg}$ 中には最大で 0.09 0.14 at \% 程 度の固溶度しかないために, Mg 粒内に La や Ce は固溶せず, 急冷時に $\mathrm{Mg}-\mathrm{Zn}-\mathrm{RE}$ の化合物として生成・分散したと考えら れる。つまり, 生成する 3 元化合物の $\mathrm{Mg}$ 濃度は $\mathrm{La}$ や $\mathrm{Ce}$ を 用いた合金の方が高いこと，さらに $\mathrm{La}$ や Ce は $\mathrm{Mg}$ にほとん ど固溶しないため, より多くの 3 元化合物が生成すると考え られる。一方, RE 元素に Gd, Tb, Dy, Ho や Erを用いた場 合では, 急冷とその後の熱処理で生成する化合物の Zn と RE 濃度が比較的高く, また添加した $\mathrm{RE}$ 元素が $\mathrm{Mg}$ に最大 4.5 6.9 at\% 固溶するため, 生成する化合物の量も少なく, $\mathrm{Mg}$ 粒内に生成する長周期相の密度も低いと考えられる。

$\mathrm{Mg}_{97} \mathrm{Zn}_{1} \mathrm{RE}_{2}$ 合金熱処理材において, RE 元素に La や Ce を 用いた場合とそれ以外の Gd, Tb, Dy, Ho や Er を用いた場 合では，Fig. 1 に示すように硬さに大きな差が認められる。 松田らにより長周期相は变形双晶を抑制することが報告され ており，Mg の硬さや強度を向上させると考えられている ${ }^{12)} 。$ 長周期相は純 $\mathrm{Mg}$ と比較して硬さむ硬く ${ }^{5)}$, また, $\mathrm{Mg}_{97} \mathrm{Zn}_{1} \mathrm{Gd}_{2}$ (at\%) 合金では溶体化処理後の低温時効により, 時効析出硬化することなども報告されており, $\mathrm{Mg}$ 粒を強化 させている一つの要因と考えられる ${ }^{13)} 。 し か し ~ M_{97} Z_{1} \mathrm{La}_{2}$ 合 金や $\mathrm{Mg}_{97} \mathrm{Zn}_{1} \mathrm{Ce}_{2}$ 合金の $\mathrm{Mg}$ 粒内には微細な $\mathrm{Mg}-\mathrm{Zn}-\mathrm{La}$ 化合物 が高密度で存在しているのに対し, Fig. 2, Fig. 6 および Fig. 14 に観察されるように, 長周期相は $\mathrm{Mg}$ 粒内にしばしば観察 される程度で，その密度は小さい。長周期相は $\mathrm{Mg}$ 合金の高 強度化に寄与するものの, その生成密度が低い場合, その効 果む小さいと考えられる。添加する $\mathrm{RE}$ 元素の違いによる $\mathrm{Mg}$ 粒径には大きな差がないため, 添加した RE 元素の違いによ る著しい硬さの差は結晶粒微細化効果による硬さの違いでは ないと考えられる。以上の結果から，これら合金の固さの違 いは 3 元化合物の生成量, 特に $\mathrm{Mg}$ 粒内の微細な化合物の生 成密度に起因していると考えられる。 $\mathrm{Mg}_{97} \mathrm{Zn}_{1} \mathrm{La}_{2}$ 合金や $\mathrm{Mg}_{97} \mathrm{Zn}_{1} \mathrm{Ce}_{2}$ 合金は, $\mathrm{Mg}$ 中に生成する 3 元化合物の生成密度 が $\mathrm{Mg}_{97} \mathrm{Zn}_{1} \mathrm{RE}_{2}$ （RE=Gd，Tb，Dy，Hoもしくは $\mathrm{Er}$ ）合金の $\mathrm{Mg}$ 中に生成する長周期相の生成密度と比較して著しく高い ため，脆いものの著しく高い硬さを示すと考えられる。

\section{4. 結言}

(1) $\mathrm{Mg}_{97} Z_{1} \mathrm{RE}_{2}$ (RE=La, Ce, Gd, Tb, Dy, Ho むしくは Er）合金熱処理材は $\mathrm{Mg}$ 粒と $\mathrm{Mg}-\mathrm{Zn}-\mathrm{RE}$ の 3 元化合物で構成 されていた。 $\mathrm{Mg}$ 粒の大きさは $0.7 \sim 2 \mu \mathrm{m}$ であり, 添加する $\mathrm{RE}$ 元素の違いによる $\mathrm{Mg}$ 粒径の大きな差は認められなかっ た。

(2) $\mathrm{Mg}_{97} \mathrm{Zn}_{1} \mathrm{RE}_{2}$ （RE=Gd, Tb, Dy, Ho むしくは Er) 合金 では, Mg 粒内にしばしば $14 \mathrm{H}$-type の長周期相が観察された。 一方, $\mathrm{Mg}_{97} \mathrm{Zn}_{1}$ ( $\mathrm{La}$ もしくは Ce) ${ }_{2}$ 合金の $\mathrm{Mg}$ 粒内には $30 \mathrm{~nm}$ 程度の微細な 3 元化合物が高密度で存在していた。このよう な化合物の生成形態の違いが硬さの差を生じさせていると考 えられる。

\section{謝 辞}

本研究は「文部科学省ナノテクノロジー総合支援プロジェ クト」による支援を受けて行った。付記して感謝申し上げま す。また, 化合物の構造解析にご助言を頂きました, 平賀賢 二東北大学名誉教授に感謝いたします。

\section{参 考 文 献}

1) Y. Kawamura, K. Hayashi, A. Inoue and T. Masumoto: Material Trans., JIM., 42 (2001), 1172-1176.

2) A. Inoue, Y. Kawamura, M. Matsusita, K. Hayashi and J. Koike: J. Mater. Res. Soc., 16 (2001), 1894-1900.

3) S. Kawaguchi, M. Sugamata and J. Kaneko: J. Japan Inst. Light Metals., 47 (1997), 3-9.

4) K. Hondo, J. Kaneko, M. Sugamata and M. Kubota: Mater. Sci. forum., 419-422 (2003), 733-738.

5) T. Itoi, T. Seimiya, Y. Kawamura and M. Hirohashi: Scripta Materialia., 51 (2004), 107-111.

6) Y. Kawamura, T. Morisaka and M. Yamasaki: Mater. Sci. Forum., 419-422 (2003), 751-756.

7) M. Nishida, T. Yamamuro, M. Nagano, Y. Norizono and Y. Kawamura: Mater. Sci. Forum., 419-422 (2003), 715-720.

8) Z. P. Luo and S. Q. Zhang: J. Mater. Sci. Lett., 19 (2000), 813-815.

9) E. Abe, Y. Kawamura, K. Hayashi and A. Inoue: Acta Materialia., 50 (2002), 3845-3857.

10) K. Amiya, T. Ohsuna and A. Inoue: Material. Trans., JIM., 44 (2003), 2151-2156.

11) M. Matsuda, S. Ii, Y. Kawamura, Y. Ikuhara and M. Nishida: Mater. Sci. Eng., 393 (2005), 269-274.

12) M. Matsuda, S. Ii, Y. Kawamura, Y. Ikuhara and M. Nishida: Mater. Sci. Eng., 386 (2004), 447-452.

13) M. Yamasaki, T. Anan, S. Yoshimoto and Y. Kawamura: Scripta Materialia., 53 (2005), 799-803. 